\title{
ANALISA PROSES DRAWING PADA PEMBENTUKAN ASBAK DENGAN KUPING BERBENTUK ALUR
}

\author{
${ }^{1}$ Idiar, ${ }^{2}$ Sugianto \\ 1,2 Jurusan Teknik Mesin, Polman Negeri Bangka Belitung \\ Kawasan Industri Airkantung Sungailiat, \\ Telp.0717-93586, Fax.0717-93585, ji.idiar@gmail.com
}

\begin{abstract}
The design of the press tool is one of the practice courses that teach the skill in designing tool forming and cutting the product from the plate. The quality of the design is determined by the ability to apply the design procedure. Competence is widely applied in the design of drawing prints with a certain level of product complexity. Practice activity of designing drawing drawing of students of Engineering Design Program of Mechanical Polytechnic of State of Bangka Belitung done conventionally, where only using drawing table or computerized depiction software then printed on drawing paper. This results in frequent errors in student design drawings. To overcome these problems required drawing prints that can form a specific product such as ashtrays, with the aim of producing a construction drawing print that can be applied and utilized in the teaching of press tool design. The method of making this tool consists of data collection, concept making, tool design, machining \& testing. Based on the results of trials that have been done, carried out on 10 blank by using a lubricant in the form of vegetable oil. Of the 10 experiments the formation showed that the central pool of ashtrays can be perfectly formed, while 4 pieces of the grooves on the ear of the ashtray have not been formed well where there are still folds or curves that are not regular.
\end{abstract}

Keywords: drawing tool, design, ashtray, aluminium

\begin{abstract}
Abstrak
Perancangan press tool merupakan salah satu mata kuliah praktik yang mengajar ketrampilan dalam merancang cetakan pembentuk dan pemotong produk dari pelat. Kualitas hasil rancangan ditentukan oleh kemampuan dalam menerapkan prosedur perancangan. Kompetensi tersebut banyak diaplikasikan dalam perancangan cetakan drawing dengan tingkat kompleksitas produk tertentu. Aktivitas praktik merancang cetakan drawing mahasiswa program studi Teknik Perancangan Mekanik Politeknik Manufaktur Negeri Bangka Belitung dilakukan secara konvensional, dimana hanya menggunakan meja gambar atau perangkat lunak penggambaran di komputer lalu dicetak pada kertas gambar. Hal tersebut menyebabkan sering terjadi beberapa kesalahan pada gambar rancangan yang dibuat oleh mahasiswa. Untuk mengatasi permasalahan tersebut diperlukan cetakan drawing yang dapat membentuk produk tertentu seperti asbak, dengan tujuan yaitu menghasilkan konstruksi cetakan drawing yang dapat diterapkan dan dimanfaatkan pada pengajaran perancangan press tool. Metode pelaksanaan pembuatan cetakan ini terdiri dari pengumpulan data, pembuatan konsep, perancangan alat, permesinan \& uji coba. Berdasarkan hasil uji coba yang telah dilakukan, dilakukan pada 10 blank dengan menggunakan pelumas berupa minyak nabati. Dari 10 kali uji coba pembentukan tersebut menunjukkan bahwa kolam bagian tengah asbak dapat dibentuk dengan sempurna, sedangkan 4 buah alur yang terdapat pada bagian kuping asbak belum terbentuk dengan baik dimana masih terdapat lipatan atau lengkungan yang tidak teratur.
\end{abstract}

Kata kunci: cetakan drawing, desain, asbak, aluminium 


\section{PENDAHULUAN}

Perancangan press tool merupakan salah satu mata kuliah praktik yang mengajar ketrampilan dalam merancang cetakan pembentuk dan pemotong produk dari pelat. Proses merancang yang dilakukan harus mengikuti persyaratan-persyaratan tertentu agar dapat mencapai kualitas rancangan sesuai dengan spesifikasi yang ditetapkan. Kualitas hasil rancangan ditentukan oleh kemampuan dalam menerapkan prosedur perancangan yaitu gabungan antara kepiawaian dalam memilih jenis subsistem pada cetakan, menentukan langkah kerja, menentukan parameter proses, dan parameter-parameter lain yang terkait dengan perancangan press tool. Kemampuan tersebut secara keseluruhan sering digunakan pada proses perancangan cetakan drawing.

Penelitian pernah dilakukan untuk mengembangkan media percobaan pada proses deep drawing di dalam sebuah laboratorium pengajaran, dimana mahasiswa harus melakukan evaluasi pada data proses deep drawing yang sebelumnya sudah dilakukan oleh tim pengajaran. Usulan inovasi dari mahasiswa dimulai dengan demonstrasi percobaan deep drawing yang dilakukan dengan media percobaan yang telah dirancang di laboratorium untuk kebutuhan penelitian dan pengajaran. Pengolahan informasi tersebut membantu mahasiswa dalam menganalisa dasar utama pada teknologi deep drawing [1].

Kegiatan pembelajaran praktik perancangan press tool khususnya materi drawing yang dilakukan oleh mahasiswa program studi Teknik Perancangan Mekanik Politeknik Manufaktur Negeri Bangka Belitung masih dilakukan secara konvensional. Aktivitas praktik merancang cetakan drawing dilakukan di laboratorium perancangan dengan menggunakan fasilitas berupa meja gambar atau perangkat lunak penggambaran di komputer. Hasil rancangan berupa gambar susunan yang dibuat atau dicetak pada kertas gambar dengan ukuran tertentu. Mahasiswa hanya mengandalkan daya bayang saja dalam menerapkan ide-ide atau teori pendukung pada rancangan cetakan yang dibuat. Kondisi tersebut menyebabkan mahasiswa kesulitan untuk memahami cara kerja cetakan dan subsistem yang ada didalamnya seperti sistem pelokasi, sistem blank holder, ejektor, dan lain-lain. Hal tersebut mempengaruhi kualitas hasil rancangan cetakan drawing yang dibuat oleh mahasiswa. Kesalahan umum yang terjadi dilakukan oleh mahasiswa dalam merancang cetakan drawing yaitu penentuan jenis dan dimensi sistem pelokasi yang tidak cocok dengan karakteristik bentuk produk yang dibuat serta konstruksi blank holder dan ejektor produk yang tidak bekerja sesuai dengan fungsinya.

Untuk membantu mahasiswa memahami cara kerja subsistem yang ada pada cetakan drawing secara komprehensif maka dibutuhkan suatu konstruksi cetakan yang dapat merepresentasikan secara lengkap satu siklus proses pembentukan produk dengan proses drawing misalnya pembentukan produk asbak dari bahan aluminium.

\section{METODE PENELITIAN}

Penelitian yang berkaitan dengan proses deep drawing dengan produk cup silindris yaitu menganalisa pengaruh dari parameter proses deep drawing dalam membentuk produk cup silindris. Material yang digunakan adalah aluminium paduan AA5754-O. Parameter proses yang dilihat pengaruhnya yaitu variasi dimensi die, kondisi gesekan, tekanan terhadap penipisan dinding dari cup silindris. Kesimpulan yang didapat dari penelitian ini bahwa die memiliki pengaruh paling besar dalam proses, jarak antara batas diameter dalam die terhadap punch, memiliki tekanan paling tinggi pada bidang kontak dengan material [2]. Dalam menyelesaikan pembuatan cetakan drawing ini, dibuat tahapan penyelesaian seperti pada diagram alir yang dapat dilihat pada Gambar 2.1. 


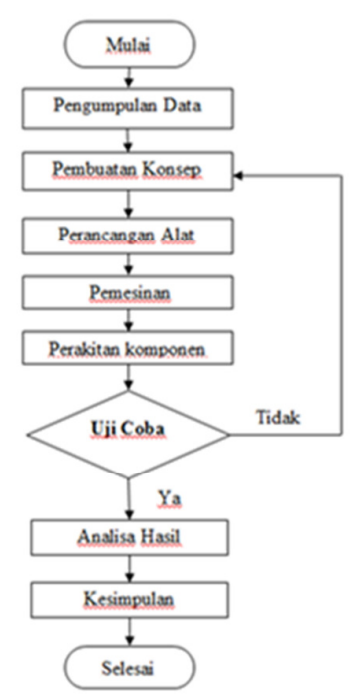

Gambar 2. Diagram alir penelitian

\section{HASIL DAN PEMBAHASAN}

\subsection{Rancangan Cetakan Drawing}

Berikut ini bentuk dan ukuran asbak yang akan dibentuk dari bahan aluminium menggunakan cetakan drawing yaitu:

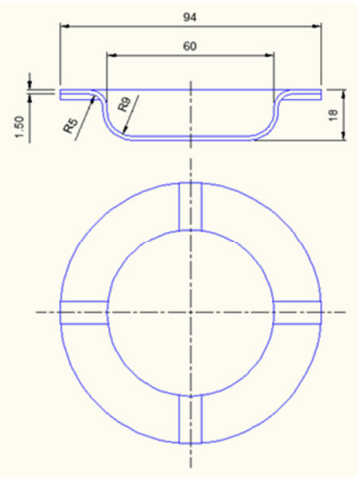

Gambar 3.1 Bentuk dan ukuran produk asbak

Cetakan drawing produk asbak aluminium yang dirancang dan dikonstruksikan dalam penelitian ini mempunyai beberapa bagian utama yang mendukung operasional kerjanya yaitu dieset, punch, die, blank holder, lokator dan ejektor. Ukuran cetakan drawing yang dibuat mempunyai dimensi $200 \times 300 \times 247 \mathrm{~mm}$, dan dibuat dengan dua buah tiang pengarah pada bagian tengah dari sisi samping cetakan sehingga memudahkan peletakan blank pada cetakan dari arah depan.

Berdasarkan bentuk dan dimensi produk tersebut diketahui data-data spesifikasi proses drawing sebagai berikut:
Diameter blank
$=112 \mathrm{~mm}$
Gaya pembentukan
$=65184 \mathrm{~N}= \pm 6,6$ Ton
Radius die
$=5 \mathrm{~mm}$
Clearance
$=1,6 \mathrm{~mm}$

Rancangan awal cetakan drawing yang dibuat dapat dilihat pada gambar di bawah ini: 

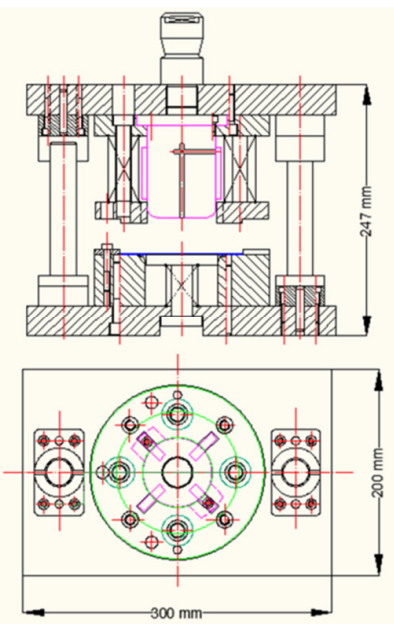

Gambar 3.2 Rancangan cetakan drawing produk asbak

Rancangan cetakan ini menggunakan 4 buah pegas tekan pada konstruksi blank holder dihitung dengan menggunakan rumus [3] sebagai berikut:

$$
P_{d b}=A_{n} \cdot P_{b} \cdot 0,001
$$

Keterangan:

$\mathrm{P}_{\mathrm{db}}=$ gaya blank holder $(\mathrm{kN})$

$A_{n}=$ area blank holder $\left(\mathrm{mm}^{2}\right)$

$\mathrm{P}_{\mathrm{b}}=$ tekanan blank holder per sat. area $\left(\mathrm{N} / \mathrm{mm}^{2}\right)$

Perhitungan gaya blank holder dihitung sebagai berikut:

$A_{n}=$ area blank holder $=5668 \mathrm{~mm} 2$

$\mathrm{P}_{\mathrm{b}}=$ tekanan blank holder per sat. area $=0,49 \mathrm{~N} / \mathrm{mm}^{2}$

Hasil perhitungan didapatkan gaya blank holder sebesar 2,777 kN sehingga diketahui masingmasing pegas blank holder sejumlah 4 buah pegas akan memberikan gaya tekan pada pelat sebesar 694,25 N. Adapun kedalaman proses penekanan dari pemukaan blank sebesar 16,5 mm, untuk mendapatkan rata-rata gaya tekan pegas sebesar 694,25 N pada blank maka diposisikan pada nilai tengah dari kedalaman penekanan yaitu sebesar $\pm 9 \mathrm{~mm}$. Pegas tekan standar yang dipilih berdasarkan data tersebut adalah tipe SL35-60.

\subsection{Pembuatan dan Perakitan Cetakan Drawing}

Proses pembuatan komponen cetakan drawing produk asbak ini dilakukan proses permesinan di beberapa mesin baik yang konvensional maupun otomatis seperti mesin CNC turning \& milling, mesin bor, mesin gerinda datar dan yang lainnya. Setelah komponen-komponen tersebut selesai diproses, selanjutnya dilakukan proses perakitan yaitu penggabungan komponen-komponen tersebut menjadi sebuah cetakan yang utuh sehingga dapat bekerja sesuai dengan fungsi sistem masing-masing.

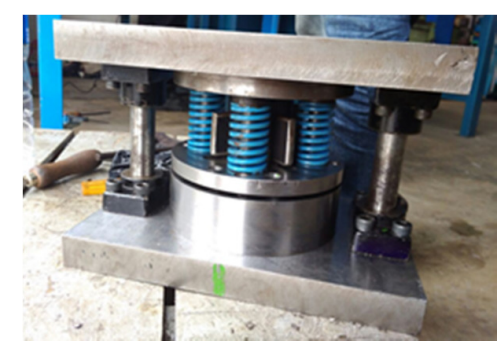

Gambar 3.3 Hasil perakitan cetakan 
Setelah dirakit dilakukan proses trial yaitu bagian cetakan bagian atas (upper die) digerakkan ke atas dan bawah, hal tersebut untuk melihat apakah sistem yang terdapat pada cetakan seperti tiang pengarah, blank holder, punch-die, ejektor sudah bekerja dengan baik atau belum. Apabila sistem yang terdapat pada cetakan tersebut sudah berfungsi, maka tahap selanjutnya adalah dilakukan uji coba pembentukan produk asbak dari bahan aluminium.

\subsection{Uji Coba \& Analisa Hasil Pembentukan}

Setelah proses pembuatan dan perakitan selesai, tahap selanjutnya dilakukan pengujian pembentukan terhadap cetakan drawing tersebut. Tujuan dari pengujian ini untuk mengetahui apakah cetakan drawing berfungsi sesuai dengan yang diharapkan yaitu mampu membentuk produk asbak dari bahan aluminium seperti bentuk dan dimensi yang diinginkan. Hasil pengujian yang telah dilakukan sebagai berikut:

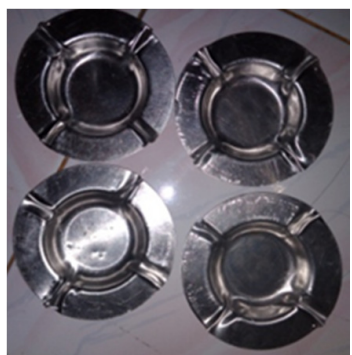

Gambar 3.4 Produk asbak hasil uji coba pembentukan pada cetakan drawing

Uji coba dilakukan pada alat press hidrolik dengan kapasitas 15 Ton. Uji pembentukan dilakukan pada 10 blank dengan menggunakan pelumas berupa minyak nabati. Dari 10 kali uji coba pembentukan tersebut menunjukkan bahwa kolam bagian tengah asbak dapat dibentuk dengan sempurna, sedangkan 4 buah alur yang terdapat pada bagian kuping asbak belum terbentuk dengan baik dimana masih terdapat lipatan atau lengkungan yang tidak teratur.

Dari pengamatan yang dilakukan pada saat proses pembentukan berlangsung diketahui penyebab lipatan/lengkungan yang tidak teratur pada 4 buah alur pada kuping asbak yaitu tidak terjadinya kontak antara permukaan die dan blank khusus pada bagian alur pada saat proses penekanan berlangsung, sehingga tegangan jepit yang diberikan oleh blank holder tidak merata pada saat blank ditarik ke dalam rongga die.

\section{SIMPULAN}

Dari hasil uji coba dan analisa produk yang didapat, dapat disimpulkan beberapa hal yaitu sebagai berikut:

1. Cetakan drawing dapat berfungsi membentuk produk asbak dari bahan aluminium sesuai dengan bentuk dan dimensi yang diinginkan secara keseluruhan.

2. Produk asbak yang dibentuk masih terdapat cacat berupa lipatan atau lengkungan yang tidak teratur pada bentuk 4 buah alur yang terdapat pada sisi bagian kuping asbak.

3. Hasil analisa menunjukkan bahwa penyebab lipatan atau lengkungan pada bentuk alur asbak tersebut disebabkan permukaan blank yang tidak kontak secara langsung/sempurna dengan permukaan die pada saat penekanan berlangsung. Hal tersebut dikarenakan pada permukaan die tersebut terdapat lubang yang berbentuk alur.

\section{DAFTAR PUSTAKA}

[1]. Eguia, V. M., Coello, J., Martinez, A., Manjabacas, M.C, Calatayud, A.,"Learning Strategis For Deep drawing Processes In The European Higher Education Area Context", Material Science Forum Trans Tech Publications, Vol. 692, hal 74-82, 2011.

[2]. Simoes, V. M. N., "Analysis Of The Influence Of Process Parameters In The Deep drawing Of A Cylindrical Cup", A Thessis Report in Mechanical Engineering In Production Systems Specialty, Universidade De Coimbra, 2012.

[3]. Tanshin, M., Press Die Design Middle Text Book, Indonesia: Indonesia Tool \& Die Industry Association, 2010. 